\title{
Öğrencilerin iç hastalıkları hemşireliği dersinin klinik uygulamasında yaşadıkları sorunlar
}

\author{
Sevda EFIL ${ }^{\mathrm{a}}$, Hilalnur KÜÇÜKAKGÜN ${ }^{\mathrm{b}}$, Elif GÜL ${ }^{\mathrm{c}}$, Merve KAPICI ${ }^{\mathrm{d}}$
}

\section{ÖZET}

\begin{abstract}
Amaç: Çalışma iç hastalıkları hemşireliği dersini almış öğrencilerin klinik uygulamalar sırasında yaşadıkları sorunları tespit etmek amacıyla yapılmıştır. Yöntem: Tanımlayıcı tipte olan çalışmanın evrenini bir üniversitenin hemşirelik bölümünde iç hastalıkları hemşireliği dersini almış öğrenciler oluşturdu. Örneklem seçimine gidilmeyip ulaşılan ve çalışmaya katılmayı kabul eden 162 öğrenciyle araştırma tamamlandı. Veriler literatür doğrultusunda araştırmacılar tarafindan hazırlanan 30 soruluk anket formuyla toplandı. Verilerin değerlendirmesinde yüzdelik ve ki-kare testleri kullanıldı. Bulgular: Öğrencilerin \%82.7'sinin kadın olduğu, \%74.7'sinin hemşirelik mesleğini sevdiği ve \%39.5'inin kendi isteğiyle bölümü seçtiği saptandı. Öğrencilerin $\% 58$ 'inin uygulamaya giderken stres yașadıkları belirlendi. Öğrencilerin \%50'den fazlası öğretim elemanı ve rehber hemşireleri rol model olarak gördüklerini belirtti. Uygulamada daha çok sorunların; malzemelere yeterince ve kolaylıkla ulaşamama (\%75.3), görev dışı sorumluluk alma (\%60.5) ve kendilerini yabancı hissetme (\%58) nedenleriyle yaşandığ saptandı. Sağl1k meslek lisesinden mezun olan öğrencilere göre diğer okullardan mezun olan (düz lise, Anadolu, lisans) öğrencilerin 'hastanın öğrenciye karşı güven sorunu yaşaması' istatistiksel olarak anlamlı oranda yüksek bulundu. Sonuçlar: Araştırma sonucunda klinik uygulamaya ilişkin belirlenen stres faktörlerinin ve karşılaşılan sorunların tartışılması ve çözüm yollarına ilişkin iyileştirme çabalarının gerçekleştirilmesi önerilmektedir.
\end{abstract}

Anahtar Kelimeler: Geribildirim, hemşirelik, iç hastalıkları, klinik uygulama, öğrenci

\section{Problems experienced by students during the clinical practice of internal disease nursing course \\ ABSTRACT}

Objective: The objective of this study is to determine the problems of students who have taken internal medicine nursing lectures during clinical practices. Methods: The population of this descriptive study consists of the students who have taken internal medicine nursing lectures in the nursing department of a university. It was aimed to study with the universe available without going to the selection of the sample. The study was completed with 162 students who have been contacted and agreed to participate in. Data were collected using a data collection form designed by the researchers based on the literature review. The form consists of 30 questions. The data were analyzed using percentages and chi-square test. Results: According to the results of the study; $82.7 \%$ of the students were females, $74.7 \%$ of them are pleased to be in the nursing profession and $39.5 \%$ of them chose to study the major at their own request. 58.02\% of the students stated that they had experienced stress while practicing and more than $50 \%$ of the students considered teaching staff and guide nurses as role models. In practice, the students experienced problems such as not being able to reach medical equipment adequately and comfortably (75.3\%), taking off-duty responsibilities $(60.49 \%)$ and alienation from work $(58.02 \%)$. It was found that "the problem of patients' not having confidence in students" is significantly high in other high school graduates (High schools, Anatolian high schools, undergraduate) than in medical vocational high school graduates. Conclusions: As a result, it is suggested that the stress factors and problems encountered regarding clinical practice and improvements to the solutions be discussed.

Keywords: Feedback, nursing, internal medicine, clinical practice, students

\footnotetext{
Geliş Tarihi:27.07.2019

Kabul Tarihi:02.11.2019

${ }^{a}$ Çanakkale Onsekiz Mart Üniversitesi, Sağlık Bilimleri Fakültesi, Hemşirelik Bölümü,,Çanakkale, Türkiye e-posta: sevda_efil@ @otmail.com, https://orcid.org/0000-0002-4988-3743

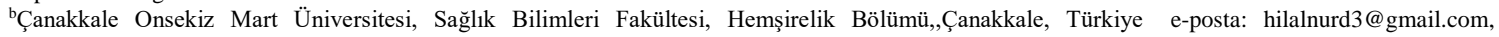
https://orcid.org/0000-0002-6454-714X

'Çanakkale Onsekiz Mart Üniversitesi, Çanakkale Sağlık Yüksekokulu, Hemşirelik Bölümü, Çanakkale, Türkiye e-posta: gulelif1997@gmail.com,

https://orcid.org/0000-0003-2510-4511

dÇanakkale Onsekiz Mart Üniversitesi, Çanakkale Sağlık Yüksekokulu, Hemşirelik Bölümü, Çanakkale, Türkiye e-posta: mervekpc1108@gmail.com, https://orcid.org/0000-0002-1824-093X
}

Sorumlu Yazar/Correspondence: Sevda Efil e-posta: sevda_efil@hotmail.com

Çalışma 17. Ulusal Hemşirelik Öğrencileri Kongresinde sözel bildiri olarak sunulmuştur.

Atıf: Efil S, Küçükakgün H, Gül E, Kapıcı M. Öğrencilerin iç hastalıkları hemșireliği dersinin klinik uygulamasında yașadıkları sorunlar. Sağlık ve Yaşam Bilimleri Dergisi 2019;1(2):1-6.

Citation: Efil S, Kucukakgun H, Gül E, Kapıcı M. Problems experienced by students during the clinical practice of internal disease nursing course. Journal of Health and Life Science 2019;1(2):1-6. 


\section{GíRiş}

Küresel sağlık sorunlarının oluşturduğu yükün artmaya devam etmesi, sağlık sorunlarıyla mücadelede ekip içinde önemli bir yeri olan hemşirelerin profesyonel yaklaşım sergileyebilecek yeterli bilgi, beceri ve donanıma sahip olmaları gerekliliğini ortaya koymaktadır. ${ }^{1,2} \mathrm{Bu}$ gerekliliğin yerine getirilebilmesi ve mesleki donanımın kazandırılabilmesi için etkin bir hemşirelik eğitiminin verilmesi sağlık bakım çıktılarını iyileştireceği gibi öğrencilerin olumlu hastane deneyimi kazanmalarına da yardımcı olacaktır. ${ }^{3-5} \mathrm{Bu}$ bağlamda, öğrencilikten profesyonelliğe geçişte teorik bilginin uygulamaya aktarılması duyuşsal ve psikomotor becerilerin geliştirilebilmesine katk1 sağladığ için $^{4,6-9}$, hem teorik hem de klinik eğitimin koşulları yetişkin eğitimine uygun olacak şekilde düzenlenmelidir. ${ }^{10}$

Klinik eğitim ortamı öğrencilerin mesleğe yönelik bilgi ve becerilerini arttırmak için hemşirenin rollerini gözlemleme ve deneyimleme imkanı sağlayan dinamik bir ortamdır. Aynı zamanda eleştirel düşünme, analiz etme, kişilerarası becerilerini geliştirme, bir ekip üyesi olarak mesleki sosyalleşme, mesleki etik ve değerleri öğrenme gibi birçok kazanımlar söz konusudur. ${ }^{4,7,8,10-}$ ${ }^{12}$ Diğer taraftan klinik ortamda öğrenmeyi etkileyen koşulların kontrolünün zor olması, etkin eğitimi sağlamada güçlük yaşanmasına neden olmaktadır. ${ }^{7} \mathrm{Bu}$ nedenle hemşirelik eğitiminin temel parçası olan klinik eğitim sürecini etkileyen sorunların belirlenmesi önemlidir.

Hemşirelik eğitimi, öğrencilere klinik becerilerini, özellikle de hasta bakım becerilerini geliştirme firsatı sunan uygulamaya dayalı bir disiplindir. ${ }^{13}$ Teori ve uygulamadan oluşan derslerden biri olan iç hastalıkları hemşireliği dersi, kronik hastalıklarla mücadelede önemli çıktılar sağlamaktadır. Dersin uygulamasında yaşanan sorunları belirlerken öğrenci görüşünün alınması etkin eğitimin önündeki engelleri belirlemede fayda sağlayacağı gibi bakım alan bireyin güvenliğini sağlama açısından da oldukça önemlidir. Aynı zamanda teorik bilginin uygulamaya aktarılabilmesi ve bu sürecin sağlıklı sürdürülmesi önemlidir. $\mathrm{Bu}$ doğrultuda klinik ortamda yaşanan sorunların ve eğitimi etkileyebilecek faktörlerin tespit edilmesi mesleki gelişime katkı sağlayacak bilgilere ulaşma imkanı sunacaktır. Böylece istenmeyen sonuçların da önüne geçilmiş olacaktır. ${ }^{14}$

Literatürde öğrencilerin klinik uygulamada yaşadıkları sorunları ele alan çalışmalar bulunmakla birlikte, sadece iç hastalıkları hemşireliği dersi uygulamasına ilişkin öğrenci geri bildirimini değerlendiren çalışma bulunmamaktadır. $\mathrm{Bu}$ nedenle literatüre katk1 sağlayacağı düşünülerek yapılan bu çalışmada iç hastalıkları hemşireliği dersini almış öğrencilerin klinik uygulama sırasında yaşadıkları sorunların onlardan alınan geri bildirimler doğrultusunda belirlenmesi amaçlandı. Araştırma Soruları:

- Hemşirelik öğrencilerinin klinik uygulama sırasında stres yaşama nedenleri nelerdir?

- Hemşirelik öğrencilerinin en son mezun oldukları okula göre uygulamada karşılaştıkları sorunlar nelerdir?

- Hemşirelik öğrencilerinin teorik bilgiyi uygulamaya aktarırken zorlanma nedenleri nelerdir?

- Hemşirelik öğrencilerinin klinik uygulamada öğretim elemanı ve rehber hemşire ile ilgili yaşadıkları sorunlar nelerdir?

\section{YÖNTEM}

$\mathrm{Bu}$ araştırma, iç hastalıkları hemşireliği dersini almış öğrencilerin uygulamada yaşadıkları sorunları tespit etmek amaciyla yapılan tanımlayıcı nitelikte bir araştırmadır.

Araştırmanın evrenini bir üniversitenin hemşirelik bölümünde eğitim gören İç Hastalıkları Hemşireliği dersini almış 3. ve 4. sınıf 252 öğrenci oluşturdu. Evrenden örneklem seçimine gidilmeyip ulaşılan, çalışmaya katılmayı kabul eden 162 öğrenci (\%64.2) çalışmaya dahil edildi.

Araştırmanın yapılacağı kurumdan yazılı izin alındı. Öğrencilere araştırmaya katılıp katılmama konusundaki kararın tamamen kendilerine ait olduğu, bu çalışmanın amacı ve toplanılacak verilerin yalnızca araştırma kapsamında kullanılacağı açıklandı. Araştırmaya katılmayı kabul eden öğrencilerden sözlü ve yazılı bilgilendirilmiş gönüllü olurları alındı.

Veriler 26 Ekim-1 Aralık 2017 tarihleri arasında araştırmacılar tarafından kaynaklar doğrultusunda hazırlanmış anket formu ile topland1. 3,4,6,11,12,14-19 Birinci bölümde sosyo-demografik ve tanıtıcı özellikler, ikinci bölümde dersin klinik uygulamasına ilişkin sorular yer aldı. Otuz sorudan oluşan formun doldurulması yaklaşık 10-15 dakika içinde tamamland1. Elde edilen veriler "Statistical Package for Social Sciences (SPSS, Inc, Chicago, IL) 20.0 for Windows" programında analiz edildi. Çalışma verileri tanımlayıc1 istatistiksel metotlar (frekans, yüzde) ve kikare analizi ile değerlendirildi. Sonuçlar yorumlanırken istatistiksel anlamlılık düzeyi $\mathrm{p}<0.05$ olarak kabul edildi.

\section{BULGULAR}

Öğrencilerin \%82.7'sinin kadın, \%76.6'sının 18-21 yaş arası, \%55.6'sının 3. sınıf, \%20.4'ünün sağlık meslek lisesi mezunu olduğu, \%74.7'sinin hemşirelik mesleğini sevdiği belirlendi. Hemşirelik bölümünü seçme nedenlerinden ilk üç sıraya bakıldığında; 
\%39.5'i kendi isteği ile, \%28.4'ü kolay iş imkanı bulma nedeni ile ve \%17.3'ünün puanı yettiği için hemşireliği seçtiği belirlendi (Tablo 1). Katılımcıların \%58'inin iç hastalıkları hemşireliği dersi uygulamasına giderken stres yaşadıkları belirlendi. Stres nedenlerinden ilk üç sıraya bakıldığında; stajın, dersin zor olması ve yoğun geçmesi (\%27.6), yetersiz bilgiye sahip olma (\%14.9) ve hastane ortamı (\%12.8) ve yanlış uygulama yapma korkusu (\%12.8) olduğu tespit edildi (Tablo 2).

Tablo 1. Öğrencilerin sosyo-demografik ve tanıtıcı özellikleri

\begin{tabular}{|c|c|c|}
\hline & $\mathbf{s}$ & $\%$ \\
\hline \multicolumn{3}{|l|}{ Cinsiyet } \\
\hline Kadın & 134 & 82.7 \\
\hline Erkek & 28 & 17.3 \\
\hline \multicolumn{3}{|l|}{ Yaş } \\
\hline $18-21$ & 124 & 76.6 \\
\hline $22-25$ & 36 & 22.2 \\
\hline 26 yaş ve üstü & 2 & 1.2 \\
\hline \multicolumn{3}{|l|}{ Mezun olduğu okul } \\
\hline Anadolu lisesi & 108 & 66.7 \\
\hline Düz lise & 19 & 11.7 \\
\hline Sağlık meslek lisesi & 33 & 20.4 \\
\hline Daha önce başka bir lisans programı bitiren & 2 & 1.2 \\
\hline \multicolumn{3}{|l|}{ Sinıf } \\
\hline 3 & 90 & 55.6 \\
\hline 4 & 72 & 44.4 \\
\hline \multicolumn{3}{|l|}{ Hemşirelik mesleğini sevme durumları } \\
\hline Evet & 121 & 74.7 \\
\hline Hayir & 12 & 7.4 \\
\hline Kararsız & 29 & 17.9 \\
\hline \multicolumn{3}{|l|}{$\begin{array}{l}\text { Hemşirelik bölümünü seçmedeki en } \\
\text { önemli neden }\end{array}$} \\
\hline Kendi isteğimle & 64 & 39.5 \\
\hline Kolay iş imkanı & 46 & 28.4 \\
\hline Puanım yettiği için & 28 & 17.3 \\
\hline Aile isteği & 24 & 14.8 \\
\hline
\end{tabular}

Tablo 2. Öğrencilerin klinik uygulama sırasında stres yașama durumlarının değerlendirilmesi

\begin{tabular}{lrr}
\hline & $\mathbf{n}$ & $\mathbf{\%}$ \\
\hline $\begin{array}{l}\text { İç hastalıkları hemşireliği dersi uygulamasına } \\
\text { giderken stres yaşama durumu }\end{array}$ & & \\
Evet & 94 & 58.0 \\
Hayır & 68 & 42.0 \\
\hline Stres yaşama nedenleri* (n=94) & & \\
Stajın, dersin zor olması ve yoğun geçmesi & 26 & 27.6 \\
Yetersiz bilgiye sahip olma & 14 & 14.9 \\
Yanlış uygulama yapma korkusu & 12 & 12.8 \\
Hastane ortamı & 12 & 12.8 \\
Klinisyen hemşirelerin olumsuz tutumu & 9 & 9.6 \\
Rehber hemşire ile yaşanan sorunlar & 6 & 6.4 \\
Dersin sorumlu öğretim elemanının disiplinli & & \\
olması & 6 & 6.4 \\
Hasta ve yakınlarının olumsuz tutumu & 3 & 3.2 \\
Belirli nedeni yok & 3 & 3.2 \\
İletişim sorunu & 2 & 2.1 \\
Yabancı uyruklu olmam nedeniyle zorlanmam & 1 & 1.0 \\
\hline *Yüzdeler n üzerinden alınmıştır. & &
\end{tabular}

Öğrencilerin uygulama alanında karşılaştıkları sorunlardan ilk üç sıraya bakıldığında ise; giyinme odasının bulunmamas1/yetersiz olması (\%75.3), görev dışı sorumluluk alma (\%60.5) ve uygulama alanında kendini yabancı hissetme $(\% 58)$ olduğu görüldü (Tablo 3). Öğrencilerin uygulamada yaşadıkları sorunlar en son mezun oldukları okula göre karşılaştırıldığında; sağlık meslek lisesinden mezun olan öğrencilere göre diğer okullardan mezun olan (düz lise, Anadolu lisesi, lisans) öğrencilerin 'hastanın öğrenciye karşı güven sorunu yaşaması' istatistiksel olarak anlamlı oranda yüksek bulundu $(\mathrm{p}<0.05)$ (Tablo 3$)$.

Tablo 3. En son mezun olunan okul ile öğrencilerin uygulama alanında karşılaştıkları sorunlar

\begin{tabular}{|c|c|c|c|c|c|c|c|c|c|}
\hline & & \multicolumn{2}{|c|}{$\begin{array}{l}\text { Sağlık Meslek } \\
\text { Lisesi }\end{array}$} & \multicolumn{2}{|c|}{$\begin{array}{l}\text { Diğer (Düz lise, } \\
\text { Anadolu, Lisans) }\end{array}$} & \multicolumn{2}{|c|}{ Toplam } & \multirow[b]{2}{*}{$\chi^{2}$} & \multirow[b]{2}{*}{$\mathbf{p}$} \\
\hline & & $\mathbf{S}$ & $\%$ & $\mathbf{S}$ & $\%$ & $\mathbf{s}$ & $\%$ & & \\
\hline \multirow{2}{*}{$\begin{array}{l}\text { Uygulama alanında kendini yabancı } \\
\text { hissetme }\end{array}$} & Evet & 18 & 54.5 & 76 & 58.9 & 94 & 58.0 & 0.206 & 0.650 \\
\hline & Hayır & 15 & 45.5 & 53 & 41.1 & 68 & 42.0 & & \\
\hline \multirow{2}{*}{$\begin{array}{l}\text { Hastane ekibi tarafindan değer } \\
\text { verilmemesi }\end{array}$} & Evet & 20 & 60.6 & 63 & 48.8 & 83 & 51.2 & 1.457 & 0.227 \\
\hline & Hayır & 13 & 39.4 & 66 & 51.2 & 79 & 48.8 & & \\
\hline \multirow{2}{*}{$\begin{array}{l}\text { Sürekli hasta odasında } \\
\text { bulunulmasının istenmesi }\end{array}$} & Evet & 20 & 60.6 & 51 & 39.5 & 71 & 43.8 & 4.739 & 0.029* \\
\hline & Hayır & 13 & 39.4 & 78 & 60.5 & 91 & 56.2 & & \\
\hline \multirow{2}{*}{$\begin{array}{c}\text { Giyinme odasının } \\
\text { bulunmamas1/yetersiz olmas1 }\end{array}$} & Evet & 26 & 78.8 & 96 & 74.4 & 122 & 75.3 & 0.270 & 0.603 \\
\hline & Hayır & 7 & 21.2 & 33 & 25.6 & 40 & 24.7 & & \\
\hline \multirow{2}{*}{$\begin{array}{c}\text { Hastanın öğrenciye karşı güven } \\
\text { sorunu yaşaması }\end{array}$} & Evet & 11 & 33.3 & 70 & 54.3 & 81 & 50.0 & 4.605 & 0.032* \\
\hline & Hayır & 22 & 66.7 & 59 & 45.7 & 81 & 50.0 & & \\
\hline \multirow[t]{2}{*}{ Görev dışı sorumluluk alma } & Evet & 21 & 63.6 & 77 & 59.7 & 98 & 60.5 & 0.171 & 0.679 \\
\hline & Hayır & 12 & 36.4 & 52 & 40.3 & 64 & 39.5 & & \\
\hline \multirow{2}{*}{$\begin{array}{l}\text { Teorik bilgileri klinikte } \\
\text { uygulayamama }\end{array}$} & Evet & 11 & 33.3 & 52 & 40.3 & 63 & 38.9 & 0.538 & 0.463 \\
\hline & Hayır & 22 & 66.7 & 77 & 59.7 & 99 & 61.1 & & \\
\hline \multirow{2}{*}{$\begin{array}{c}\text { Malzemelere (eldiven, maske, } \\
\text { antibakteriyel jel, vb.) yeterince ve } \\
\text { kolaylıkla ulaşamama }\end{array}$} & Evet & 9 & 27.3 & 31 & 24.0 & 40 & 24.7 & 0.149 & 0.700 \\
\hline & Hayır & 24 & 72.7 & 98 & 76.0 & 122 & 75.3 & & \\
\hline \multirow[t]{2}{*}{ Klinik ortamın huzursuz olması } & Evet & 14 & 42.4 & 41 & 31.8 & 55 & 33.9 & 1.327 & 0.249 \\
\hline & Hayır & 19 & 57.6 & 88 & 68.2 & 107 & 66.1 & & \\
\hline \multirow{2}{*}{$\begin{array}{c}\text { Hasta ile ilgili yazılı verilere } \\
\text { ulaşmakta zorlanma }\end{array}$} & Evet & 8 & 24.2 & 38 & 29.5 & 46 & 28.4 & 0.351 & 0.553 \\
\hline & Hayır & 25 & 75.8 & 91 & 70.5 & 116 & 71.6 & & \\
\hline
\end{tabular}




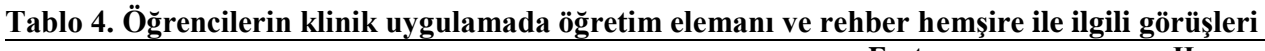

\begin{tabular}{lcccc}
\hline & Evet & Hayır & \% \\
\hline Öğretim elemanını rol model görme durumları & 118 & 72.8 & 44 & 27.2 \\
\hline Rehber hemşireyi rol model görme durumları & 93 & 57.4 & 69 & 42.6 \\
\hline $\begin{array}{l}\text { *Öğretim elemanı ve rehber hemşire ile yaşadıkları } \\
\text { sorunlar }\end{array}$ & & & & \\
\hline Uygulama performansının yeterli ölçülememesi & 66 & 40.7 & 96 & 59.3 \\
\hline Dersle ilgili tüm kliniklere çıkamama & 55 & 33.9 & 107 & 66.1 \\
\hline Bazı uygulamaları öğrenci ile birlikte yapmama & 52 & 32.1 & 110 & 67.9 \\
\hline Motivasyonu arttırııı davranış sergilenmemesi & 50 & 30.9 & 112 & 69.1 \\
\hline İletişim sorunu yaşama & 47 & 29.0 & 115 & 71.0 \\
\hline $\begin{array}{l}\text { Uygulama notlarının öğrencinin ara sınav notuna göre } \\
\text { verildiğini düşünme }\end{array}$ & 44 & 27.2 & 118 & 72.8 \\
\hline Sürekli klinikte bulunmaması & 37 & 22.8 & 125 & 77.2 \\
\hline Geri bildirimlerin değerlendirmeye alınmaması & 29 & 17.9 & 133 & 82.1 \\
\hline Kuşak çatışması & 17 & 10.5 & 145 & 89.5 \\
\hline Diğer & 3 & 1.9 & 159 & 98.1 \\
\hline *Birden fazla secenek isaretlenmistir. & & & &
\end{tabular}

*Birden fazla seçenek işaretlenmiştir.

Sağlık meslek lisesi mezunu olan öğrencilerin ise uygulamada karşılaştıkları sorunlar içerisinde "sürekli hasta odasında bulunulmasının istenmesi' diğer mezunlara göre istatistiksel olarak anlamlı oranda daha yüksek olduğu belirlendi $(\mathrm{p}<0.05)$ (Tablo 3$)$.

Öğrencilerin \%72.8'inin öğretim elemanını uygulama alanlarında bakım ve tedaviler konusunda kendilerine rol model olarak gördüklerini ifade ettikleri belirlendi. Katılımcıların öğretim elemanı ve rehber hemşire ile yaşadıkları sorunlara bakıldığında; performansının yeterli ölçülmemesi (\%40.7), dersle ilgili tüm kliniklere çıkamama (\%33.9) ve bazı uygulamaların öğrenci ile birlikte yapılmamasını (\%32.1) ilk üç sırada ifade ettikleri görüldü (Tablo 4).

Öğrencilerin \%33.33’ünün teorik bilgiyi uygulamaya aktarırken zorlandıkları belirlendi. Teorik bilgiyi uygulamaya aktarırken zorlanma nedenlerine bakıldığında; teorik eğitim ile klinik uygulamanın örtüşmemesi (\%9.9), yetersiz bilgiye sahip olma (\%5.6) ve belirli bir neden olmamasına rağmen zorlanmayı (\%4.9) ilk üç sırada ifade ettikleri bulundu (Tablo 5).

Tablo 5. Öğrencilerin teorik bilgiyi uygulamaya aktarırken zorlanma nedenleri

\begin{tabular}{lll}
\hline $\begin{array}{l}\text { Teorik bilgiyi uygulamaya aktarmada } \\
\text { zorlanma durumu }\end{array}$ & S & \\
\hline Evet & 54 & 33.3 \\
\hline Hayır & 108 & 66.7 \\
\hline Zorlanma nedenleri & & \\
\hline $\begin{array}{l}\text { Teorik eğitim ile klinik uygulamanın } \\
\text { Örtüşmemesi }\end{array}$ & 16 & 9.9 \\
\hline Yetersiz bilgiye sahip olma & 9 & 5.6 \\
\hline Belirli bir nedeni yok & 8 & 4.9 \\
\hline $\begin{array}{l}\text { Klinisyen hemşirelerin beklentileri ile } \\
\text { ögrencilerin beklentilerinin çatışması }\end{array}$ & 6 & 3.7 \\
\hline Stres yapıyor olma & 6 & 3.7 \\
\hline Uygulamanın zor ve yoğun olması & 5 & 3.1 \\
\hline $\begin{array}{l}\text { Okul ortamında uygulama yapma imkanının } \\
\text { olmaması }\end{array}$ & 2 & 1.2 \\
\hline Rehber hemşirenin tutumu & 1 & 0.6 \\
\hline Öğrenci sayısının fazla olması & 1 & 0.6 \\
\hline
\end{tabular}

\section{TARTIŞMA}

Klinik eğitim ortamı öğrenci ve diğer paydaşlar arasında karmaşık, stresli bir süreç olsa da öğrencinin mesleki gelişimi ve bağımsız profesyonel yaklaşım sergileyebilmesi için kritik öneme sahiptir. Bu bağlamda, geleceğin hemşireleri olan öğrencilerin gerekli mesleki bilgi, beceri ve anlayışı kazanmaları için uygun koşulların yer aldığı klinik ortamlarda eğitim almaları gereklidir. ${ }^{10,20}$ Uygun koşulların sağlanması için hemşirelik öğrencilerin klinik uygulamada karşılaştıkları zorlukların belirlenmesi, saptanan sorunların çözümlenebilmesi için yol gösterecektir. Ayrıca iyileştirişi ve geliştirici adımların atılması için sonraki eğitim dönemlerine de 1 şık tutacaktır. $\mathrm{Bu}$ nedenle çalışmada öğrencilerinin iç hastalıkları hemşireliği uygulamasında yaşadıkları sorunlar değerlendirildi. Elde edilen bulgular aşağıdaki başlıklar altında tartışıldı.

\section{Öğrencilerin klinik uygulamada stres yaşama nedenleri}

Stres faktörlerinin belirlenmesi ve kontrolünün sağlanması etkin bir klinik eğitim süreci için gereklidir. ${ }^{6,14,17,20-23}$ Hemşirelik öğrencileri, eğitimleri süresince birçok farklı stres faktörlerini deneyimlemekte, strese neden olan durumların kontrolü sağlanamadığında eğitim sürecini ve mesleki kimlik gelişimini olumsuz etkilemektedir. ${ }^{15,18,20,21}$ Öğrencinin korku ve stres yaşamadan uygulama ortamını deneyimlemesi ve karşılaştığı sorunları ifade edebilmesi için eğiticiler ve klinisyen hemşireler tarafindan sergilenecek yaklaşım destekleyici olmalıdır. Fakat literatürde hemşirelik öğrencilerinin en çok stres yaşama nedenlerinin genellikle klinisyen hemşire ve eğiticiden kaynaklandığı görülmektedir. ${ }^{5-}$ 8,11,12,15,16,19,21-23 Öğrenciler literatürün aksine en s1k uygulamanın zor ve yoğun olması nedeni ile stres yaşadıklarını belirtmişlerdir. Bu farklılığın nedeninin 
hemşirelik öğrencilerinin çoğunun öğretim elemanı ve rehber hemşireleri rol model olarak görmeleri ve klinisyen hemşirelerin olumlu yaklaşımı olabileceği düşünülmektedir.

\section{Öğrencilerin uygulama alanında karşılaştıkları Sorunlar}

Öğrencilerin uygulamada sorun yaşamaları klinikte istendik davranışları yerine getirmede zorlanmalarına neden olmaktadır. ${ }^{15,16,24}$ Çalışmada, öğrencilerin uygulamada yaşadıkları sorunların sıklıkla klinik eğitim ortamında öğrenci için uygun koşulların olmamas1 (Giyinme odası, malzeme temini, hastane ekibinin yaklaşımı vb.) şeklinde ifade edildiği görülmektedir. Öğrencilerin ifade ettikleri bu sorunların nedeni; uygulamaya çıkılan ildeki hastanelerin fiziksel koşullarının yetersiz olması, haftada bir gün uygulamaya çıkılması ve klinisyen hemşirelerin öğrencilerden beklentilerinin farklı olmasından kaynaklanabilir. Çalışmada, diğer mezun öğrencilerde "hastanın öğrenciye karşı güven sorunu yaşamasının" sorun olarak görülmesinin nedeni; sağlık meslek lisesi mezunu olan öğrenciler gibi lise eğitimlerinde klinik uygulama yapılmaması olabilir. Sağlık meslek lisesi mezunu öğrencilerinin ise sorun olarak: sürekli hasta odasında bulunulmasının istenmesini istatistiksel olarak anlamlı oranda daha fazla ifade etmelerinin nedeninin öğrenci ile hemşirenin beklentilerinin örtüşmemesinden kaynaklanabileceği düşünülmektedir.

Literatürde öğrenciye yeterli zaman ayrılmaması ve ögretim elemanı sayısının yetersiz olması nedeni ile öğrencilerin uygulamada sorun yaşadıkları belirlenmiştir. ${ }^{16,19}$ İç hastalıkları hemşireliği uygulamasında her klinikten sorumlu olan öğretim elemanı veya rehber hemşire iç rotasyondaki öğrencilerle de ilgilenmektedir. Bu durum öğrencilere de sorun olarak yansımaktadır. Çalışmada öğrencinin yarısından fazlasının öğretim elemanı ve rehber hemşireyi uygulama alanlarında bakım ve tedaviler konusunda kendilerine rol model olarak gördükleri belirlenmiştir. İyi bir iletişim ve işbirliği içinde ekip çalışmasının sürdürüldüğü, iyi rol model sergileyen eğiticilerin olduğu klinik ortamlar öğrencilerin mesleki gelişimlerine olumlu yansımakta ve mesleği sevmelerine neden olmaktadır..$^{3-5,22,24} \mathrm{Bu}$ doğrultuda çalışmada öğrencilerin çoğunun eğiticileri rol model olarak görmelerinin bilgi, beceri ve deneyim kazanmalarında olumlu katkısı olacağı düşünülmektedir. Diğer taraftan öğrenciler performanslarının değerlendirilmesi, dersle ilgili uygulama yapılan servisler ve eğiticilerle yapılan uygulamalarla ilgili yaşadıkları sorunları ifade etmişlerdir. Literatürde uygulamaya çıkılmadan önce amaç ve beklentilerin, performans değerlendirmesinin anlatılması, uygulamaya ilişkin sorunları önleyebileceği gibi öğrencinin sorumluluklarını bilmesine de katkı sağlayacağı ifade edilmiştir., ${ }^{6,20}$
Belirtilen sorunlarla ilgili uygun geri bildirimde bulunulması öğrencilerin becerilerinin gelişmesine, performans güçlerini, yeterliliklerini ve eksikliklerini tanımalarına yardımcı olacaktır. ${ }^{14} \mathrm{Bu}$ nedenle öğrenciye uygun geri bildirimde bulunulmalıdır. ${ }^{14,20,25}$

Klinik uygulama öncesi öğrencilere ve rehber hemşirelere hedef, beklenti ve performans değerlendirmesi anlatılmış, her uygulama sonrası geri bildirim alınmıştır. Buna rağmen öğrenci sayısının fazla olması, uygulamaya çıkılan alanların fiziki koşullarının yetersiz olması, haftanın bir günü uygulamaya çıkılması gibi nedenlerle bu sorunlar ifade edilmiş olabilir. Ayrıca hemşire sayısı ve öğretim elemanı sayısı artmadığı sürece, öğrenci sayısının fazla olması nedeniyle, uygulamaya çıkılan servislerde de klinik eğitim ortamında uygun koşulların sağlanmasının zor olacağı düşünülmektedir.

\section{Öğrencilerin teorik bilgiyi uygulamaya aktarmada zorlanma nedenleri}

Hemşirelik eğitiminde temel sorunlardan birisi öğrencinin teorik bilgiyi uygulamaya yeterince aktaramamasıdır. ${ }^{7,9,16,26}$ Çalışmada da benzer şekilde öğrencilerin teorik bilgiyi uygulamaya aktarırken zorlandıkları görülmektedir. Klinisyen hemşirelerin öğrencilere destek olması, uygulamada yardımcı olmaları gerekliliği bilinmesine rağmen ${ }^{4,6,10,24}$, öğrencilerin klinisyen hemşirelerden yeterli desteği alamadıklar1 $1^{3-6,16,24}$ ve bu nedenle teorik bilgiyi uygulamaya aktarmada zorlandıkları belirtilmiştir. 4,7,16,24 Uygulama öncesi klinisyen hemşireler ile uygulamaya ilişkin beklenti ve hedeflerin tartışılması, her hafta iç ve dış paydaşlardan uygulamaya ilişkin geri bildirim alınması ve bu doğrultuda adımlar atılması yararlı olabilir. $\mathrm{Bu}$ sonuçlar doğrultusunda oluşabilecek sorunlara yönelik uygun geri bildirimde bulunmayı kolaylaştıracak alternatif çözüm yollarının önceden belirlenmesinin önemli olduğu düşünülmektedir. Bununla birlikte öğrenciden, hemşireden ve diğer paydaşlardan beklenen hedeflerin netleştirilmesi, uygulama öncesi hedeflerin paylaşılması ve hedeflere yönelik eylem planının oluşturulması önemlidir.

\section{SONUÇ}

Çalışmada, iç hastalıkları hemşireliği dersi klinik uygulamasında öğretim elemanı ve rehber hemşireyi rol model olarak gören öğrencinin yarısından fazla olduğu görüldü. Bununla birlikte uygulamaya giderken stres yaşadıkları, teorik bilgiyi uygulamaya aktarırken zorlandıkları belirlendi. Uygulamada yaşadıkları sorunların ise genellikle klinik öğrenme ortamı ile ilgili olduğu görüldü. $\mathrm{Bu}$ sonuçlar doğrultusunda, klinik performansın düzeltilmesi veya güçlendirilmesi için sorunların tespit edilmesi, sorunlara yönelik uygulanan çözümlerin sonuçlarının da değerlendirilmesinin önemli olduğu düşünülmektedir. Bu nedenle uygulama 
sürecini sorunsuz bir şekilde yürütmeyi sağlayacak yazılı formların yer aldığı takip sisteminin oluşturulması önerilebilir. Ayrıca öğrencinin sorun yaşamasına neden olabilecek durumlar ayrı başlıklar halinde sorgulanmalıdır. İç hastalıkları hemşireliği uygulamasına ilişkin tespit edilen sorunlar doğrultusunda bir sonraki eğitim öğretim dönemi için planlamaların yapılması, uygulanması öğrencinin etkin klinik eğitim almasının önündeki engelleri aşabilme ve mesleki gelişimine katkı sağlayacağı düşünüldüğü için önemlidir.

\section{KAYNAKLAR}

1. Akdemir N, Özdemir L, Akyar İ. Türkiye'de mezuniyet sonrası eğitim kapsamında iç hastalıkları hemşirelik eğitiminin durumu. Anadolu Hemşirelik ve Sağlık Bilimleri Dergisi. 2011;14(1):50-58.

2. Keski Ç, Karadă A. Hemşirelik son sınıf öğrencilerinin hemşirelik süreci hakkındaki bilgi düzeylerinin incelenmesi. Hemşirelikte Araştırma Geliştirme Dergisi. 2010;12(1):41-52.

3. Akgün KM, Aras T, Akarsu Ö. Hemşirelik öğrencilerinin klinik hemşirelerinin eğitimlerine verdiği katkıya ilişkin görüşleri. Cumhuriyet Hemşirelik Dergisi. 2012;2(1):29-46.

4. Aydın YD, Orak NŞ, Gürkan A, Aslan G, Demir F. Hemşirelik öğrencilerinin klinik eğitimleri sirasında hemşirelerden aldığı desteğin değerlendirilmesi. JAREN. 2017;3(3):109-115.

5. Baraz S, Memarian R, Vanaki Z. Learning challenges of nursing students in clinical environments: A qualitative study in Iran. $J E d u c$ Health Promot. 2015;4:52.

6. Biçer S, Ceyhan YŞ, Şahin F. Hemşirelik öğrencileri ve klinik hemşirelerin klinik uygulamada öğrenciye yapılan rehberlik ile ilgili görüşleri. Florence Nightingale Hemşirelik Dergisi. 2015;23(3):215-223.

7. Karaöz S. Hemşirelik eğitiminde klinik değerlendirmeye genel bakış: Güçlükler ve öneriler. DEUHYO ED. 2013;6(3):149-158.

8. Rafiee G, Moattari M, Nikbakht AN, Mousavinasab M. Problems and challenges of nursing students' clinical evaluation: A qualitative study. Iran J Nurs Midwifery Res. 2014;19(1):4149.

9. Şendir M, Çelik S, Dişsiz M et al. Hemşirelik eğitimi ve uygulamasında yeni bir yaklaşım: Hemşirelik eğitimi ve uygulamasının bütünleşmesi. JAREN. 2018;4(2):92-99.

10. Papp I, Markkanen M, von Bonsdorff M. Clinical environment as a learning environment: student nurses' perceptions concerning clinical learning experiences. Nurse Educ Today. 2003;23(4):262268.

11. Aydoğan S. Hemşirelik öğrencilerinin klinik beceri kazanmaları sırasında karşılaştıkları etik problemler. Türkiye Biyoetik Dergisi. 2016;3(2):120-123.

12. Ergin E, Çevik K, Çetin SP. Hemşirelik öğrencilerinin eğitimlerine ilişkin algıladığı stres ve stresle bas etme davranışlarının incelenmesi. Hemşirelikte Eğitim ve Araştırma Dergisi. 2018;15(1):16-22.
13. Becker MK, Neuwirth JM. Teaching strategy to maximize clinical experience with beginning nursing students. J Nurs Educ. 2002;41(2):89-91.

14. Allen L, Molloy E. The influence of a preceptorstudent 'Daily Feedback Tool' on clinical feedback practices in nursing education: A qualitative study. Nurse Education Today. 2017;49:57-62.

15. Altıok HÖ, Üstün B. Hemşirelik öğrencilerinin stres kaynaklar1. Educational Sciences: Theory \& Practice. 2013;13(2):747-766.

16. Aydın MF, Argun MŞ. Bitlis Eren Üniversitesi Sağlık Yüksekokulu hemşirelik bölümü öğrencilerinin hastane uygulamalarından beklentileri ve karşıllaştıkları sorunlar. Acıbadem Üniversitesi Sağlık Bilimleri Dergisi. 2010;1(4):209-213.

17. Bayar K, Çadır G, Bayar B. Hemşirelik öğrencilerinin klinik uygulamaya yönelik düşünce ve kayg1 düzeylerinin belirlenmesi. TAF Preventive Medicine Bulletin. 2009;8(1):37-42.

18. Edwards D, Burnard P, Bennett K, Hebden U. A longitudinal study of stress and self-esteem in student nurses. Nurse Educ Today. 2010;30:78-84.

19. Kumcağız H, Koyuncu S, Aydın G et al. Samsun Sağlık Yüksekokulu hemşirelik bölümü ögrencilerinin kuramsal ve uygulamalı eğitimde yaşadıkları sorunların belirlenmesi. Ondokuz Mayls Üniversitesi Tip Dergisi. 2005;22(2):71-77.

20. Bearman M, Molloy E, Ajjawi R, Keating J. Is there a plan B: Clinical educators supporting underperforming students in practice settings. Teaching in Higher Education. 2012;18(5):531544.

21. Karaca A, Yıldırım N, Ankaralı H, Açıkgöz F, Akkuş D. Hemşirelik öğrencilerinin algılanan klinik stres düzeyi, stres cevapları ve başetme davranışları. Psikiyatri Hemşireliği Dergisi. 2017;8(1):32-39.

22. Elçigil A, Sarı HY. Hemşirelik öğrencilerinin klinik eğitiminde kolaylaştırıcı faktörler. DEUHYO ED. 2011;4(2):67-71.

23. Karadağ G, Kilıç SP, Ovayolu N, Ovayolu Ö, Kayaaslan H. Öğrenci hemşirelerin klinik uygulamada karşılaştıkları güçlükler ve klinik hemşireler hakkındaki görüşleri. TAF Preventive Medicine Bulletin. 2013;12(6):665-672.

24. Kostak MA, Aras T, Akarsu Ö. Hemşirelik öğrencilerinin klinik hemşirelerin eğitimlerine verdiği katkıya ilişkin görüşleri. Cumhuriyet Hemşirelik Dergisi. 2012;2:39-46.

25. Luhanga F, Yonge O, Myrick F. Strategies for precepting the unsafe student. Journal for Nurses in Staff Development. 2008;24(5):214-219.

26. Akyüz A, Tosun N, Yıldız D, Kılıç A. Klinik öğretimde hemşirelerin, kendi sorumluluklarına ve hemşirelik öğrencilerinin çalışma sistemine ilişkin görüşleri. TSK Korиyиси Hekimlik Bülteni. 2007;6(6):459-464. 